\title{
Sciendo
}

DOI: $10.1515 /$ sspjce-2019-0014

\section{Characterization of sandstones of eastern Slovakia}

\author{
Pavol Jaroš, Marián Vertal' \\ Technical University of Košice, Slovakia \\ Faculty of Civil Engineering, Institute of Architectural Engineering \\ email: pavol.jaros@tuke.sk, marian.vertal@tuke.sk
}

\begin{abstract}
The main building material in the past was stone. Geological composition influenced the choice and type of building stone, which was used for the construction of the buildings. In eastern Slovakia sandstone was used in large quantities for its good compressive properties, good workability and aesthetic appearance. Sandstones were used for decorative but mainly construction purposes. The most common problem in historical stone structures is missing waterproofing insulation. Transmission and storage parameters of heat and water of historical materials are needed to assess the moisture condition of buildings and to correctly design measures. In this article are presented researches of sandstones properties abroad and locations of selected sandstones of eastern Slovakia, which were used for construction of historical buildings.
\end{abstract}

Key words: historical building, sandstone, hygrothermal properties, water absorption coefficient

\section{Introduction}

At present, great emphasis is placed on reducing the energy performance of buildings. In order to achieve the energy and climate objectives of the European Union, it is necessary to reduce the energy burden on new and existing building [1]. The construction industry is one of the largest energy consumers, uses a large amount of energy and releases a significant amount of greenhouse gases. European countries have succeeded in reducing the energy consumption of new buildings by more than $50 \%$ [2]. When designing new buildings, there is only a small investment needed to be low-energy. However, reducing the energy performance of existing buildings is much more difficult and demanding [3]. Renovation and modernization of historical buildings has an important role to play in reducing greenhouse gas emissions [2]. To design the correct measures it is necessary to know the material properties of the materials used in historical constructions. In eastern Slovakia, sandstone was used in large quantities for construction of buildings. It was used for its good workability, 
compressive strength and aesthetic appearance. The used sandstone's transmission and storage parameters of the heat and water are necessary for correct assessment. The thermal and hygric properties of sandstones determine the thermal and moisture behaviour of the building. Only a few scientists in the world have studied these properties of natural sandstones [4].

\section{Hygrothermal properties of sandstones in world}

In locations of the Czech Republic Koči el al. worked on hygric, thermal and mechanical properties of three sandstones from Kocbeře, Libnava and Záměl [5].

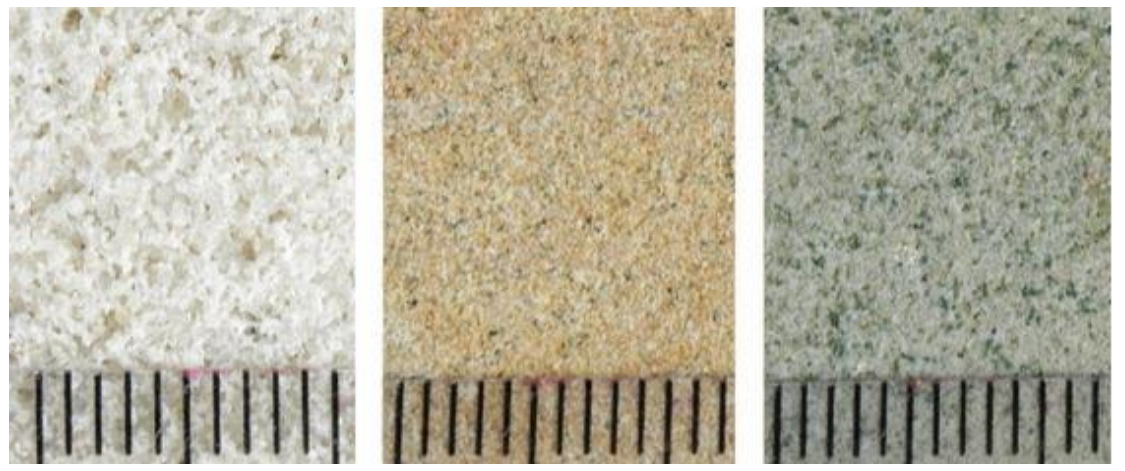

Figure 1: Appearance of measured sandstones from localities Kocbeře, Libnava, Záměl,

(Czech republic) [15]

Sandstones from locality Kocbeře and Libnava are fine-grained and sandstone from locality Záměl is medium-grained. All sandstones have high content of quartz. Properties such as bulk density, open porosity, thermal conductivity coefficient, specific heat capacity, diffusion resistance factor and water absorption coefficient are shown Table 1 [5].

\begin{tabular}{|c|c|c|c|c|c|c|}
\hline Locality & $\rho\left(\mathrm{kg} / \mathrm{m}^{3}\right)$ & $\theta_{\text {por }}\left(\mathrm{m}^{3} / \mathrm{m}^{3}\right)$ & $\lambda(\mathrm{W} / \mathrm{m} . \mathrm{K})$ & $\mathrm{c}(\mathrm{J} / \mathrm{kg} \cdot \mathrm{K})$ & $\mathrm{u}(-)$ & $\mathrm{A}_{\mathrm{w}}\left(\mathrm{kg} / \mathrm{m}^{2} . \mathrm{s}^{0.5}\right)$ \\
\hline Kocbeře & 2227.7 & 0.161 & 3.53 & 754 & 12.7 & - \\
\hline Libnava & 2191.0 & 0.179 & 2.71 & 721 & 11.6 & - \\
\hline Záměl & 2075.9 & 0.228 & 2.10 & 694 & 11.8 & - \\
\hline
\end{tabular}

Table 1: Hygrothermal properties of sandstones of Czech Republic [5]

Martin Krus focused on studying the basic properties of four types of sandstones and their influence on thermal and moisture behaviour in Germany. He studied properties of German sandstones such as Baumberger, Obernkirchner, Ruthener and Sander, which are shown in Table $2[6]$.

\begin{tabular}{|c|c|c|c|c|c|c|}
\hline Locality & $\rho\left(\mathrm{kg} / \mathrm{m}^{3}\right)$ & $\theta_{\text {por }}\left(\mathrm{m}^{3} / \mathrm{m}^{3}\right)$ & $\lambda(\mathrm{W} / \mathrm{m} . \mathrm{K})$ & $\mathrm{c}(\mathrm{J} / \mathrm{kg} \cdot \mathrm{K})$ & $\mathrm{u}(-)$ & $\mathrm{A}_{\mathrm{w}}\left(\mathrm{kg} / \mathrm{m}^{2} . \mathrm{s}^{0.5}\right)$ \\
\hline Baumberger & 1980 & 0.230 & - & - & 20 & 0.044 \\
\hline Obernkirchner & 2150 & 0.140 & - & - & 32 & 0.046 \\
\hline Ruthener & 1950 & 0.240 & - & - & 17 & 0.300 \\
\hline Sander & 2120 & 0.170 & 1.60 & 850 & 33 & 0.020 \\
\hline
\end{tabular}

Table 2: Hygrothermal properties of sandstones in Germany [6] 
The influence of anisotropy on the thermal and hygric properties of four German sandstones was investigated by Jianhua Zao and Rudolf Plagge. The sandstones studied were Arholzen, Karlshafen, Sander, Schleerither. Sandstone Arholzen and Karlshafen are fine-grained and red colored, while Karlshafen is little bit darker. Sander is brownish to olive green and has fine to medium large grains. Sandstone Schleerither is fine-grained and has a gray-green coloration [4].
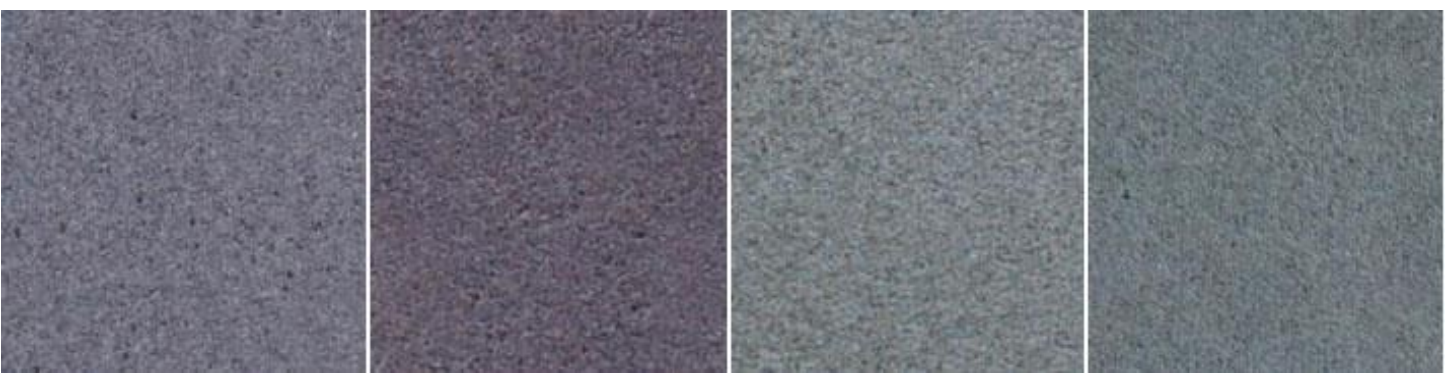

Figure 2: Sandstones in Germany from left Arholzen, Karshafen, Sander, Schleerither [4]

The measured thermal and hygric properties of sandstones are shown in Table 3.

\begin{tabular}{|c|c|c|c|c|c|c|c|}
\hline Locality & Orientation & $\begin{array}{c}\rho \\
\left(\mathrm{kg} / \mathrm{m}^{3}\right)\end{array}$ & $\begin{array}{c}\theta_{\text {por }} \\
\left(\mathrm{m}^{3} / \mathrm{m}^{3}\right)\end{array}$ & $\begin{array}{c}\lambda \\
(\mathrm{W} / \mathrm{m} . \mathrm{K})\end{array}$ & $\begin{array}{c}\mathrm{c} \\
(\mathrm{J} / \mathrm{kg} \cdot \mathrm{K})\end{array}$ & $\mathrm{u}_{\mathrm{dry}}(-)$ & $\begin{array}{c}\mathrm{A}_{\mathrm{w}} \\
\left(\mathrm{kg} / \mathrm{m}^{2} \cdot \mathrm{s}^{0.5}\right)\end{array}$ \\
\hline \multirow{2}{*}{ Arholzen } & Perpendicular & \multirow{2}{*}{2276.1} & \multirow{2}{*}{0.149} & 2.54 & 788 & 97.6 & 0.017 \\
\hline & Parallel & & & 2.54 & 828 & 61.8 & 0.020 \\
\hline & Anisotropy (\%) & - & - & 0 & 4.8 & 36.7 & 15 \\
\hline \multirow{3}{*}{ Karlshafen } & Perpendicular & \multirow{2}{*}{2415.7} & \multirow{2}{*}{0.099} & 3.28 & 796 & 178.5 & 0.006 \\
\hline & Parallel & & & 3.50 & 792 & 118.5 & 0.009 \\
\hline & Anisotropy (\%) & - & - & 6.3 & 0.5 & 33.6 & 33.3 \\
\hline \multirow{2}{*}{ Sander } & Perpendicular & \multirow{2}{*}{2032.4} & \multirow{2}{*}{0.233} & 1.41 & 717 & 25.9 & 0.056 \\
\hline & Parallel & & & 1.41 & 678 & 24.2 & 0.087 \\
\hline & Anisotropy (\%) & - & - & - & 5.4 & 6.6 & 35.6 \\
\hline \multirow{3}{*}{ Schleerither } & Perpendicular & \multirow{2}{*}{2261.9} & \multirow{2}{*}{0.162} & 1.97 & 774 & 25.5 & 0.024 \\
\hline & Parallel & & & 2.07 & 773 & 24 & 0.030 \\
\hline & Anisotropy (\%) & - & - & 4.8 & 0.1 & 5.9 & 20 \\
\hline
\end{tabular}

Table 3: Influence of anisotropy [4]

These values show us that anisotropy does not have a major influence on the thermal properties of selected sandstones. Sander and Schleerither diffusion resistance factor's values have only low grain dependence. However, the difference in the diffuse resistance factor of Arholzen and Karlshafen is more than $30 \%$. High dependence on grain direction is also shown by the values of the water absorption coefficient, the lowest Arholzen sandstone, the highest Sander sandstone.

The properties of two Canadian sandstones were studied by Mukhopadhyaya et al., which were used for wall cladding [7]. Nepean sandstone was used for the renovation of the Parliament building in Ottawa, the construction of churches, town halls and Prime Ministers building [11]. Sandstone Saint-Canut from Laurentides is white-gray and is used for the production of tiles [7]. The measured hygrothermal properties are shown in Table 4. 


\begin{tabular}{|c|c|c|c|c|c|c|}
\hline Locality & $\rho\left(\mathrm{kg} / \mathrm{m}^{3}\right)$ & $\theta_{\text {por }}\left(\mathrm{m}^{3} / \mathrm{m}^{3}\right)$ & $\lambda(\mathrm{W} / \mathrm{m} . \mathrm{K})$ & $\mathrm{c}(\mathrm{J} / \mathrm{kg} . \mathrm{K})$ & $\mathrm{u}(-)$ & $\mathrm{A}_{\mathrm{w}}\left(\mathrm{kg} / \mathrm{m}^{2} . \mathrm{s}^{0.5}\right)$ \\
\hline Nepean & 2380 & - & 0.99 & - & - & 0.003 \\
\hline St. Canut & 2495 & - & 1.04 & - & - & 0.007 \\
\hline
\end{tabular}

Table 4: Hygrothermal properties of Canadian sandstones [7]

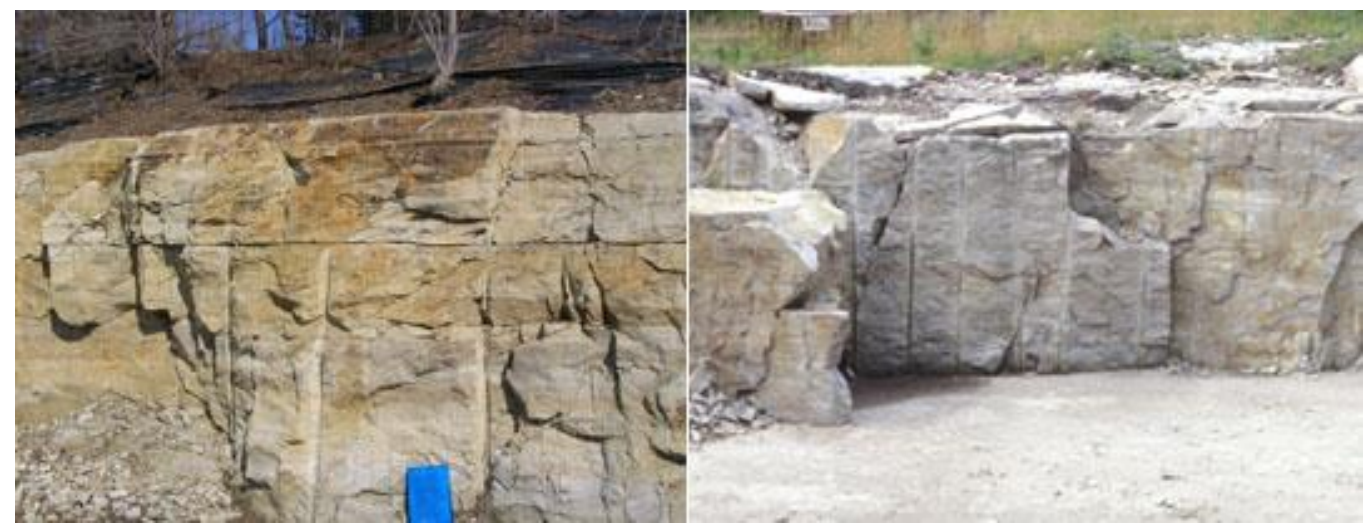

Figure 3 left: Sandstone Nepean [16], right : Sandstone St. Canut [17]

\section{Sandstone of eastern Slovakia used in building construction}

\subsection{Sandstone as a building material in the past}

Sandstone belongs to the group of sedimentary rocks. They arise from the process of weathering and disintegration of rocks into sandy grains. The resulting incoherent rocks are solidified by the process of diagnosis, which results in the formation of reinforced sandstones [8].

Sandstone deposits in the territory of the Slovak Republic are predominantly found in flysch zone in the areas of Kysuce, Orava and northeastern Slovakia. At the beginning of the $13^{\text {th }}$ century, after the advent of the Gothic art style, sandstone was the main building material. This artistic style had strict requirements for the choice of building stone. Sandstone due to its good compressive strength, good workability and aesthetic appearance was a suitable material for the construction of buildings in the Gothic style. By the end of the $19^{\text {th }}$ century, 336 quarries for sandstone mining were registered in the territory of eastern Slovakia [9]. 


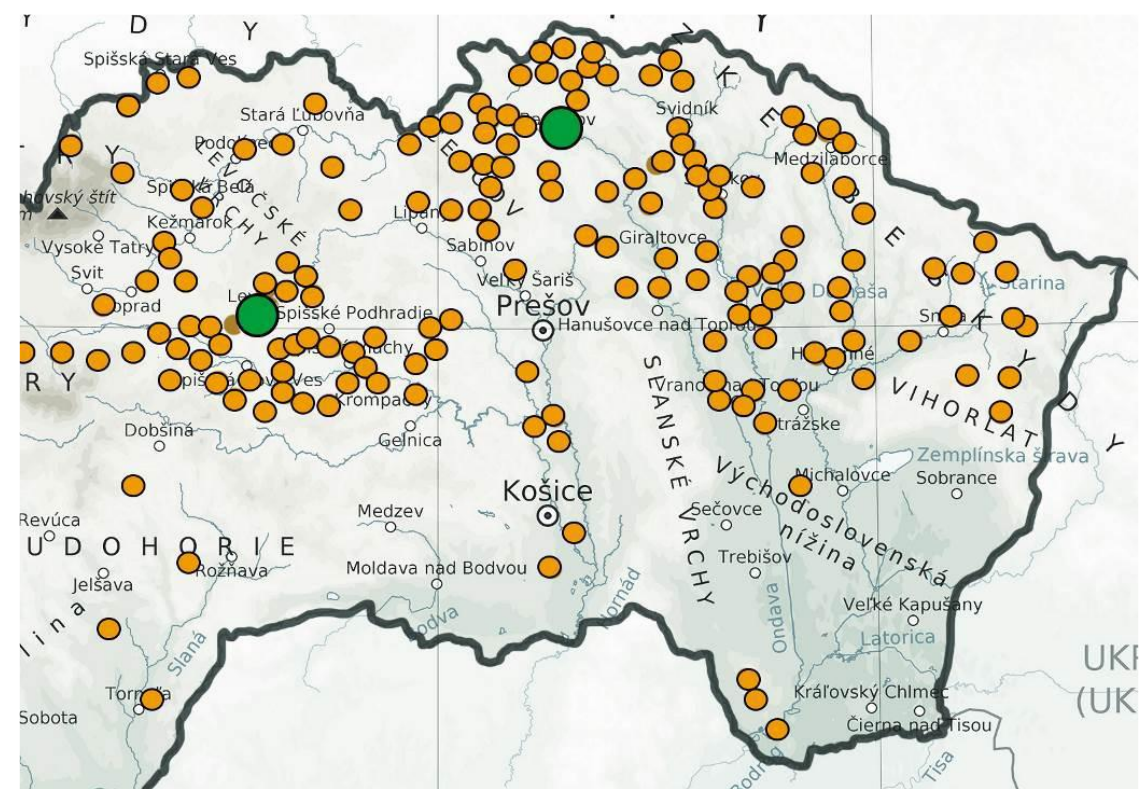

Figure 4: Localization of sandstone quarries in eastern Slovakia [9]

Major towns in which sandstone was mined include Stará L’ubovňa, Kežmarok, Levoča, Spišská Nová Ves and Bardejov. At present all historical quarries are abandoned and dilapidated. The only bearing used for sandstone mining is in Spišské Tomášovce near Spišská Nová Ves. Sandstone was used for all kinds of building such as town halls, churches, mansions, town houses, etc. It was also used for decorative purposes due to its good workability. Portals, ledges, epitaphs, railings, etc. were made from them.

\subsection{Sandstone from Kežmarok}

Kežmarok is one of the oldest historical towns in the Slovak republic. Like others, its construction began after the onset of the gothic style. The territory of the city falls under the flysch zone. On the north-east side, there is an abandoned sandstone quarry. At present, the quarry is overgrown with greenery, hardly accessible. Sandstone has light to gray color and with grain size from 0,063 to 2 it belongs to fine-grained.

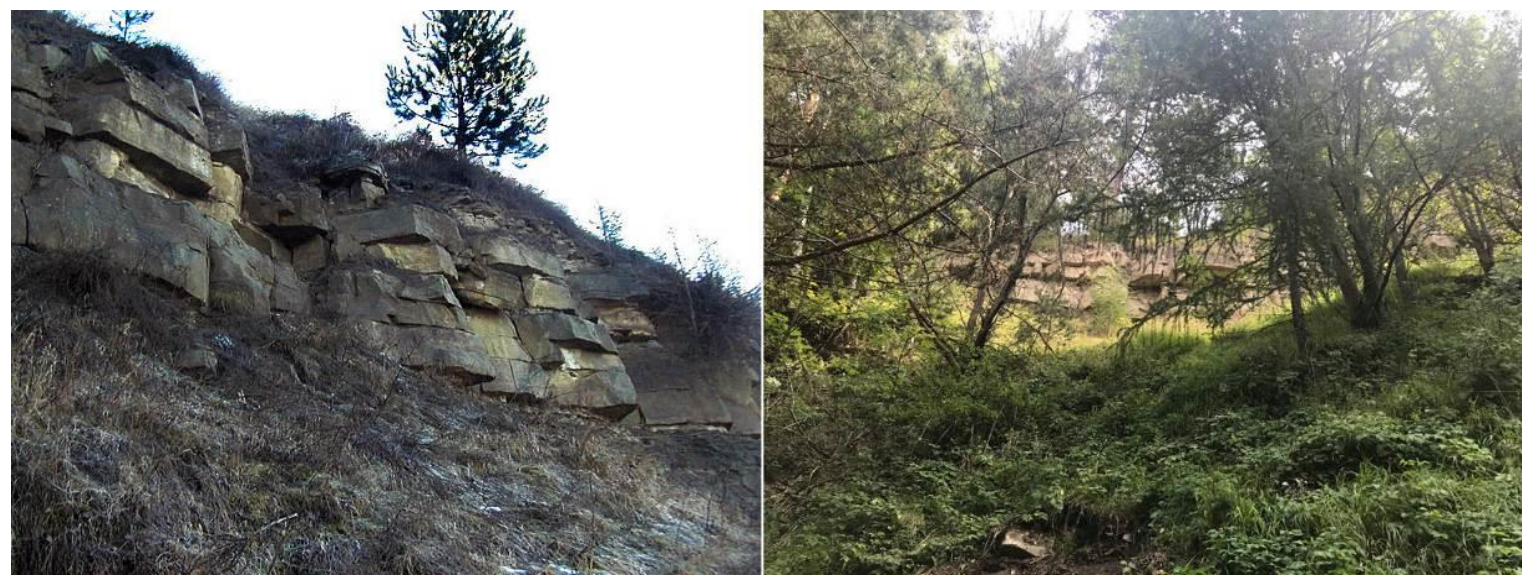

Figure 5 left: Historic quarry Kežmarok, photo [18], right : photo Jaroš, 2019) 
In the Middle Ages, sandstone was used for local construction purposes. Construction masters used sandstone for construction of churches, town houses, etc. It was used in large quantities to create entrance portals, which can be seen in the main square. This light colored sandstone was used in the construction of the Basilica of the Holy Cross from 1444, the historic bell tower, the church of the Visitation of the Virgin Mary from 1772, but also for smaller chapels.

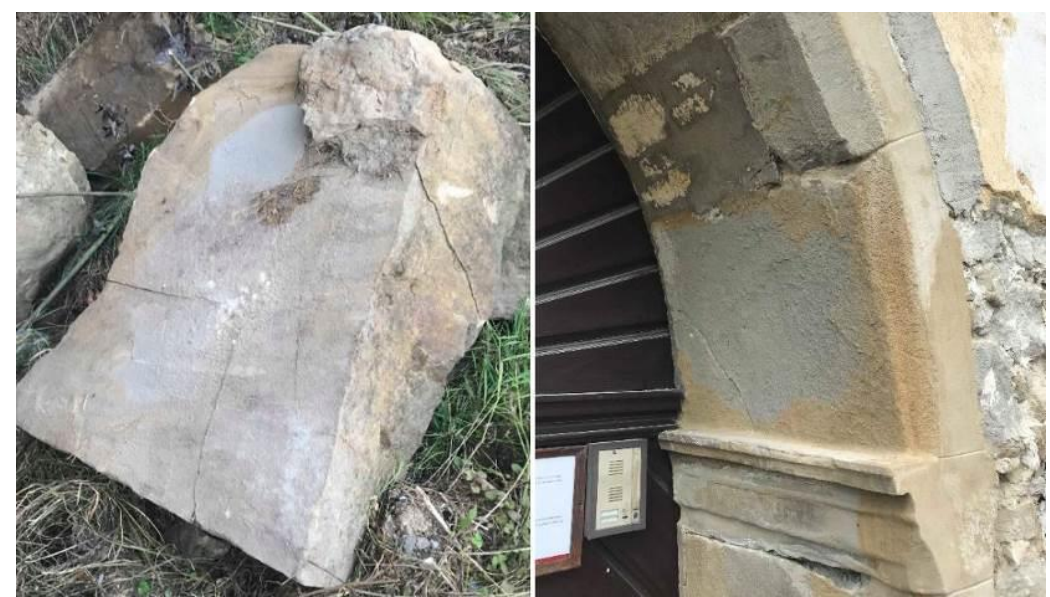

Figure 6 left: sandstone Kežmarok, right : entrance portal, Museum of housing Culture, (photos Jaroš, 2019)

During the interior reconstruction, sandstone was also discovered in the masonry of the Museum of Housing Culture at the Main Square in Kežmarok. There is also an entrance portal made of this light colored sandstone.

\subsection{Sandstone from Stará L'ubovňa - Kremná}

North of the town Stará L'ubovňa there is an abandoned quarry for the mining of sandstone Stará Lubovňa - Kremná. This sandstone, like sandstone from Kežmarok, falls under the flysch zone. It has a light, gray and yellow-brown color. Grain sizes from 0.002-2 are classified as fine-grained.
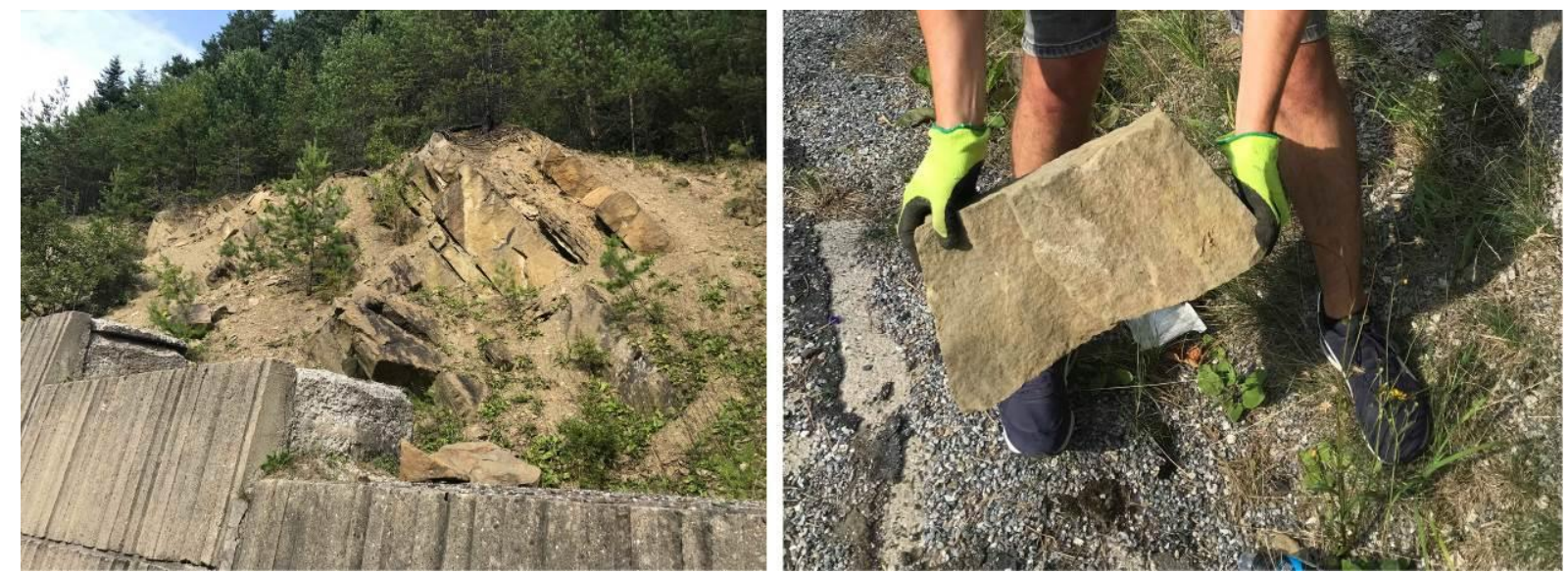

Figure 7 left: quarry Stará L’ubovňa - Kremná, right : sandstone Stará L’ubovňa, (photos Jaroš, 2019) 
In the past, it was used for local construction purposes. It was used as a building stone but also for decorative and aesthetic purposes. Fractions of this sandstone were found in the Stará Lubovňa castle (13 ${ }^{\text {th }}$ century), and also in the masonry of st. Michael's Roman Catholic Church (end of $13^{\text {th }}$ century).
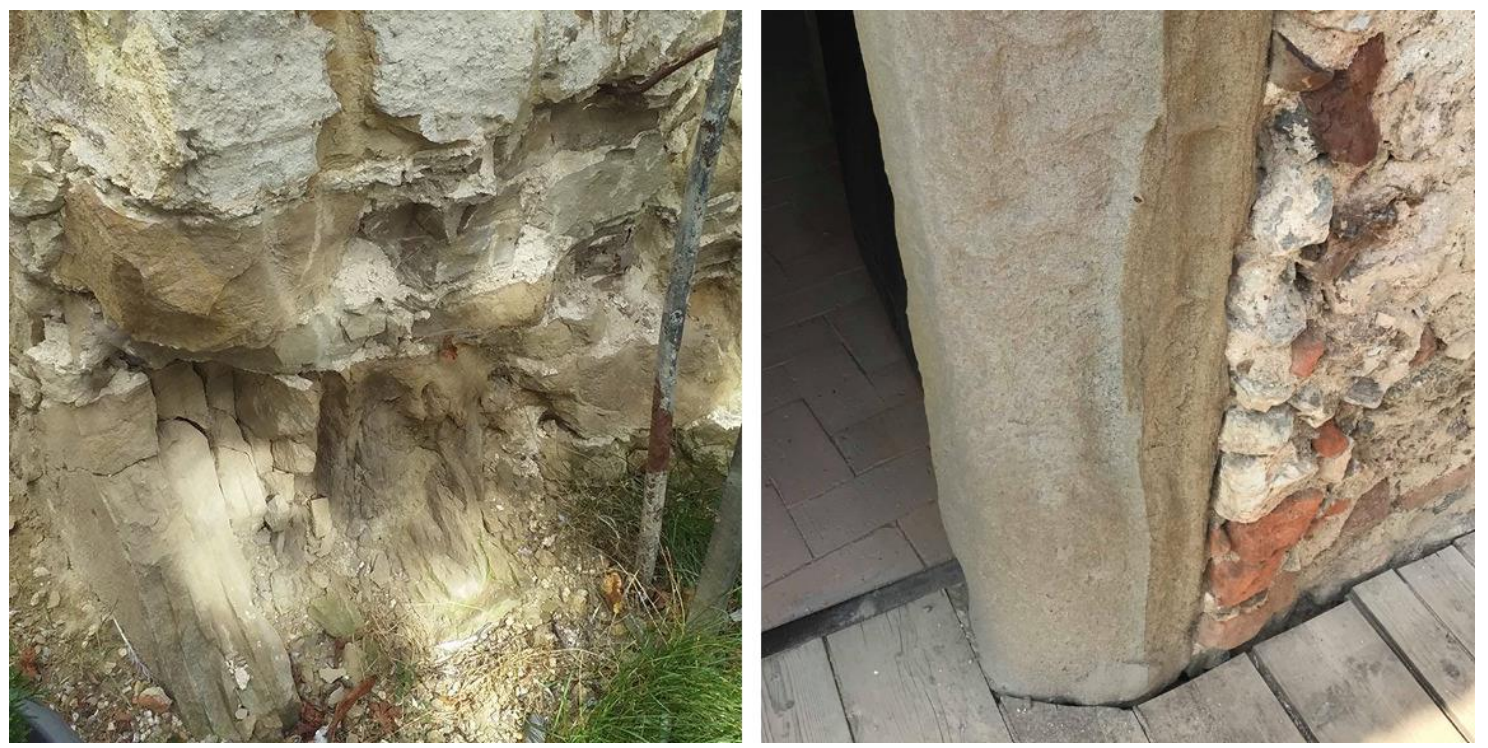

Figure 8 left : masonry of church St. Nicholas, right : portal in the castle of Stará Lubovňa, (photos Jaroš, 2019)

\subsection{Sandstone from Spišská Nová Ves - Spišské Tomášovce}

West of the town of Spišská Nová Ves there is an active quarry for the mining of sandstone Spišské Tomášovce. This sandstone, like others, belongs to the flysch zone. It has a light to gray color. Grain sizes from 0.002 to 2 are fine grains. Currently, there continues an active mining. It is used for production of aggregates for civil engineering and civil engineering purposes. Crushed aggregate is not suitable for concrete purposes, because it contains pyrite. 


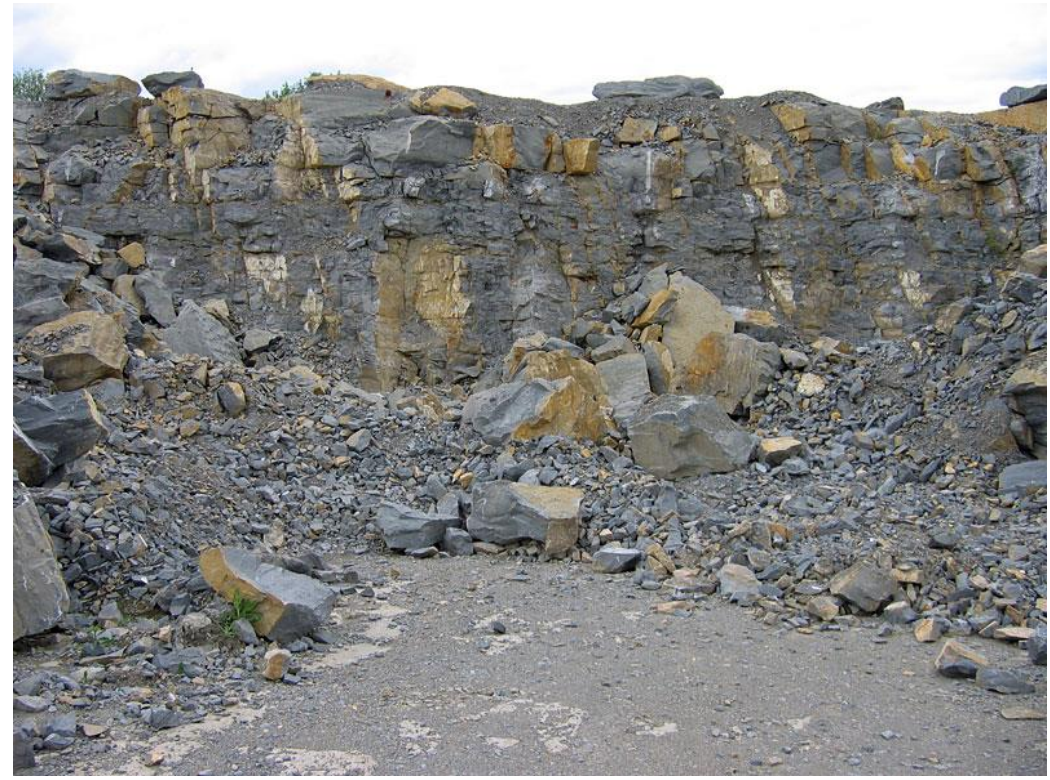

Figure 9: Quarry for mining of sandstone Spišské Tomášovce (photo Jaroš, 2019)

According to research of engineering geologists from Comenius University in Bratislava, the sandstone of Spišské Tomášovce is not suitable for restoration of historical buildings in terms of block dimensions (min. $600 \mathrm{~mm}$ ), but it is suitable for its compressive strength. It also shows good frost resistance Chyba! Nenašiel sa žiaden zdroj odkazov.

\section{Heat and water transfer parameters - water absorption coefficient, capillary water content}

\subsection{Preparation of samples for measurement}

One of the transmission parameters of water which is important for HAM simulation, is the water absorption coefficient and capillary water content. These parameters are determined by a one-dimensional water transport experiment. Prism or cylinder - shaped samples are stored in a reservoir of water. To prevent one dimensional transport of water it is necessary to insulate the sides with waterproof and vapor-proof material. It is important to insulate the sides so that water does not rise in the space between the sample and the insulating material. The top base is also resistant to vapor transmission, but there are holes for expelling the air pushed out of the pores [12].

The measuring instrument shall include a device for maintaining a constant water level, a balance accurate to $0,01 \mathrm{~g}$, an over with air ventilation $\left(70^{\circ} \mathrm{C}\right)$, a length measuring device, an air-conditioned room capable of maintaining the temperature at $\pm 20^{\circ} \mathrm{C}$ [14]. Area of samples according to [13] should be minimal $50 \mathrm{~cm}^{2}$. According to [14] the dimensions of the base shall be either $70 \times 70 \mathrm{~mm}$ or $50 \times 50 \mathrm{~mm}$ with a height of $70 \mathrm{~mm}$ or $50 \mathrm{~mm}$. Samples may be untreated after cutting. Before measurement, the samples must be dried in a desiccator at a temperature $\pm 70^{\circ} \mathrm{C}$ [14]. The specimens are made from homogeneous batches using an electric saw with a stone blade. Base dimensions 50x50 mm with a height of $70 \mathrm{~mm}$. 


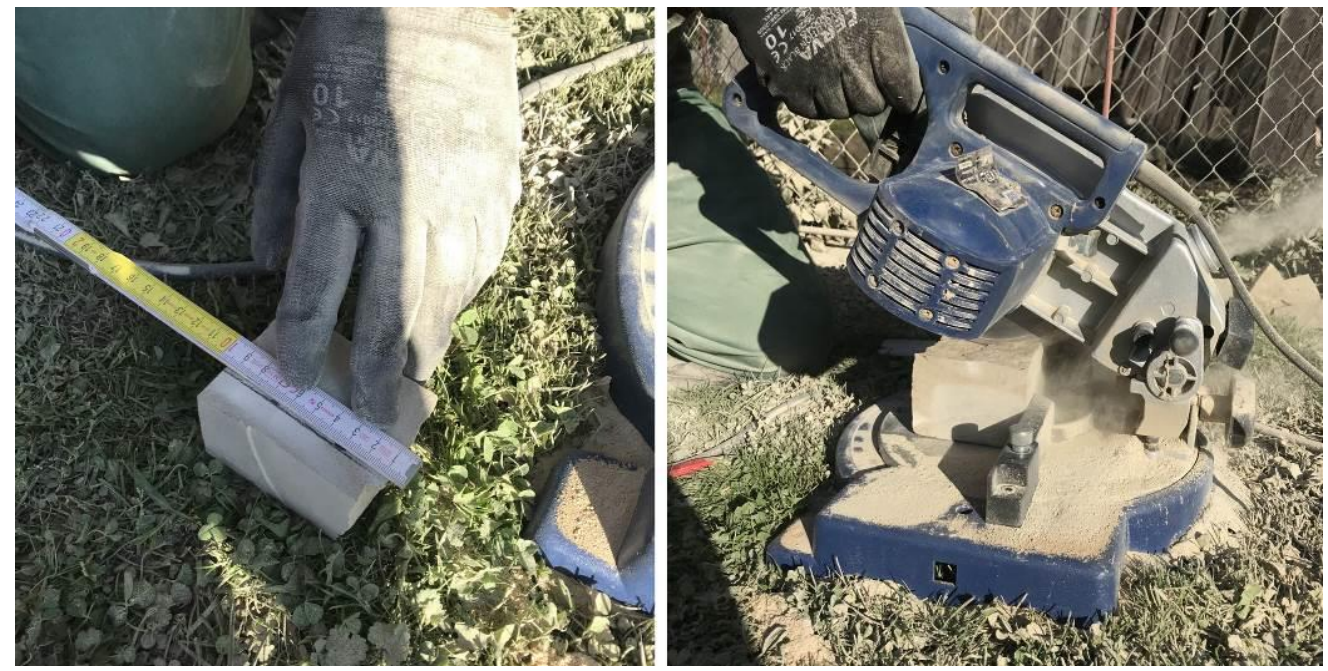

Figure 10: Preparation of sandstone samples

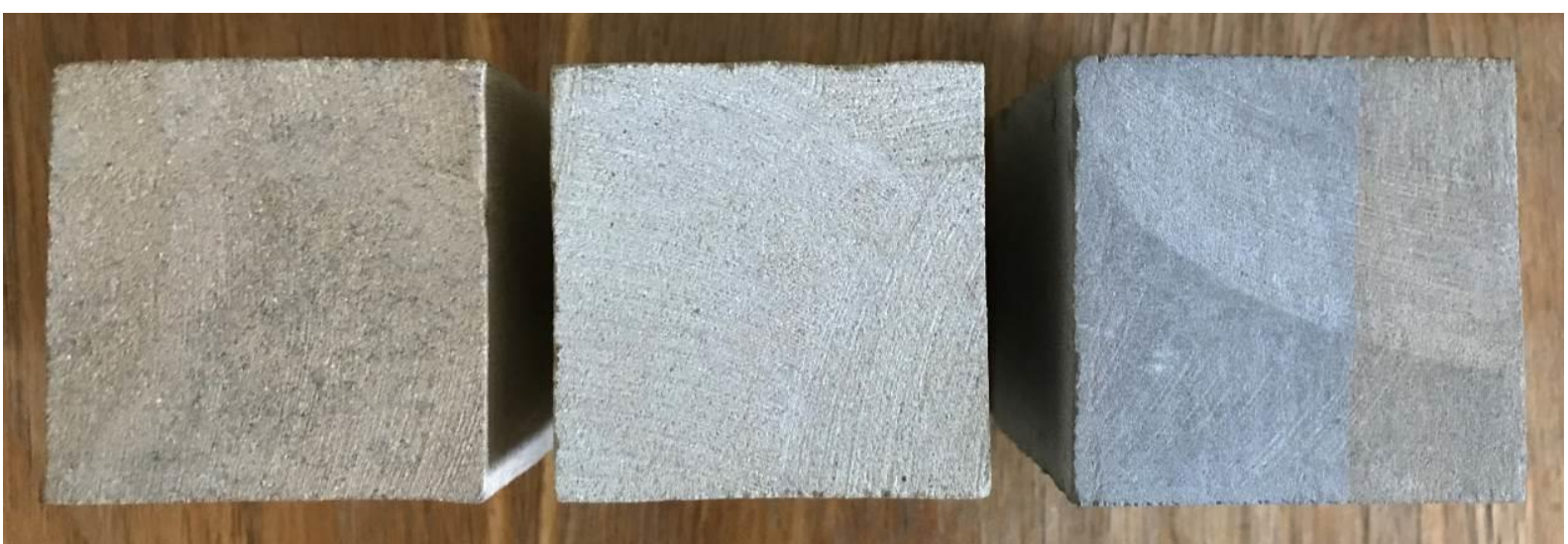

Figure 11: Samples of sandstones top view : from the left: Kežmarok, Stará Lubovňa - Kremná, Spišské Tomášovce

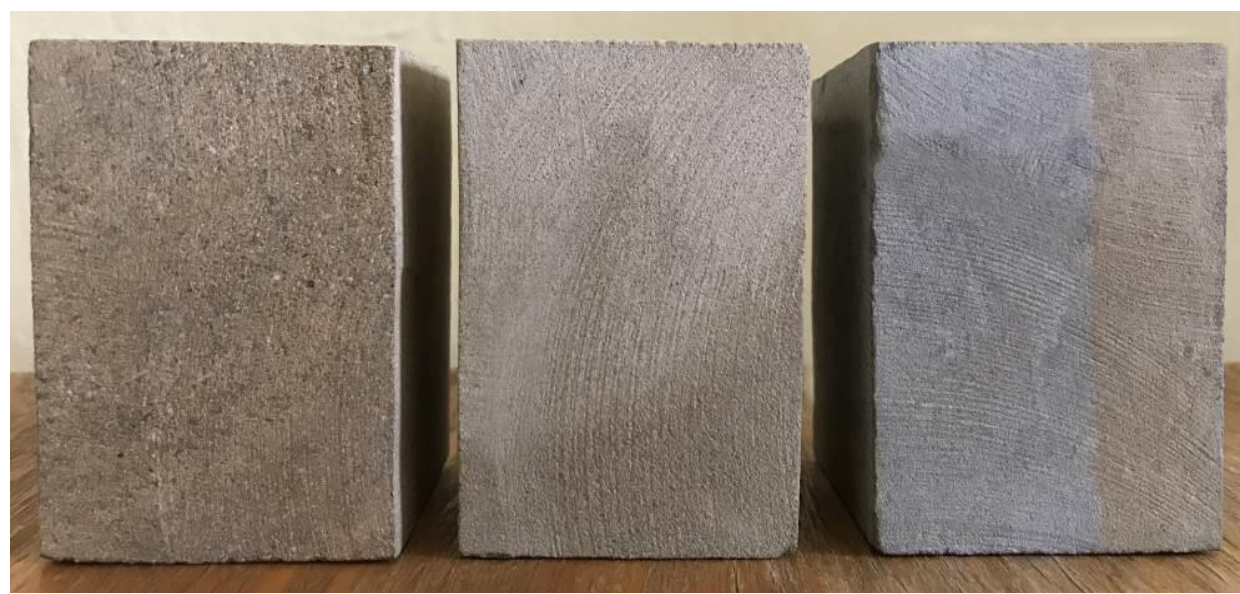

Figure 12: Samples of sandstones - front view : Kežmarok, Stará Lubovňa - Kremná, Spišské Tomášovce 
A measuring set was constructed for measurement of water absorption coefficient and capillary water content. The device consists of an analytical balance, holder for holding the sample in water, container with distil water and timer. The instrument is connected to a computer for automatically recording weight gain over time.

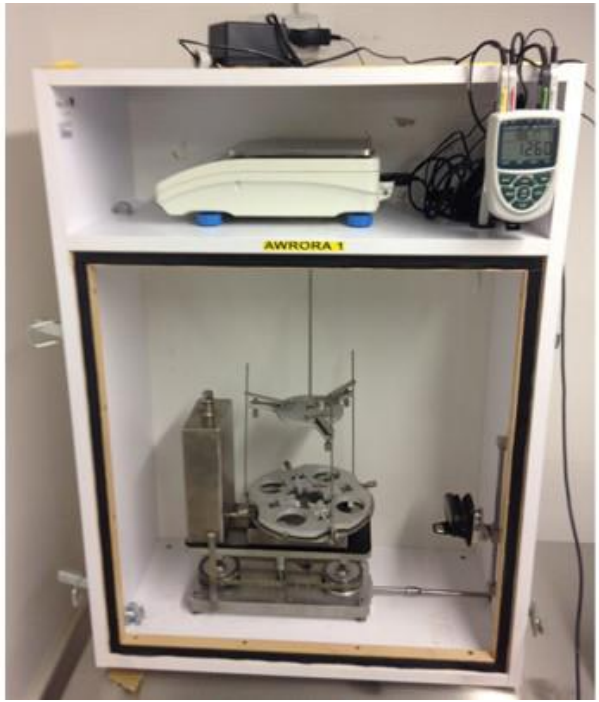

Capillary absorption - Sandstone Spišské Tomášovce

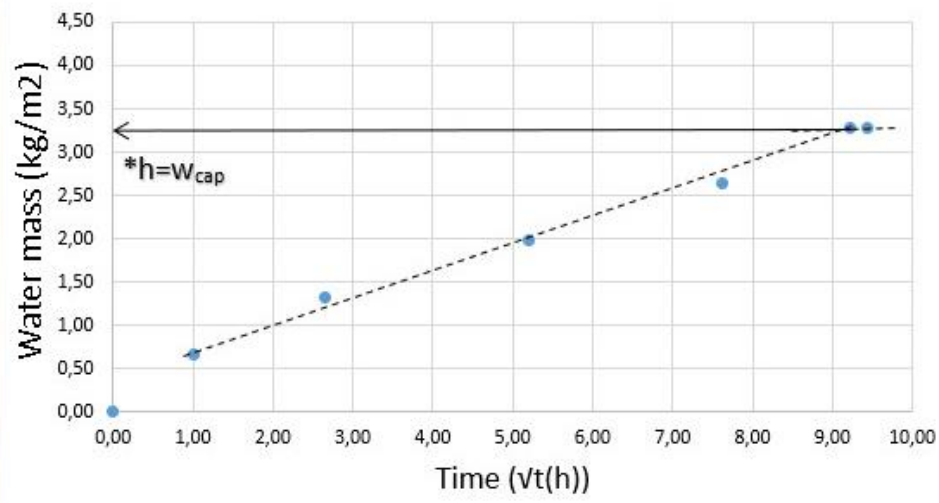

Figure 13 left: measuring set (AWRORA), right : water absorption course

The water absorption coefficient can be determined by following equation:

$$
A_{\text {cap }}=\frac{m_{w e t}-m_{d r y}}{\sqrt{t}}
$$

where $A_{\text {cap }}$ is water absorption coefficient $\left(\mathrm{kg} / \mathrm{m}^{2} \cdot \mathrm{s}^{0,5}\right), m_{\text {wet }}$ is water mass $\left(\mathrm{kg} / \mathrm{m}^{2}\right)$ per area $S\left(\mathrm{~m}^{2}\right), m_{d r y}$ is weight of dry sample $\left(\mathrm{kg} / \mathrm{m}^{2}\right)$ per area $S\left(\mathrm{~m}^{2}\right), t$ is time.

The capillary water content can be determined by following equation:

$$
w_{\text {cap }}=\frac{m_{w e t}-m_{\text {dry }}}{A} \cdot \frac{1}{H}
$$

where $w_{\text {cap }}$ is capillary water content $\left(\mathrm{kg} / \mathrm{m}^{3}\right), m_{\text {wet }}$ is water mass $\left(\mathrm{kg} / \mathrm{m}^{2}\right)$ per area $S$ $\left(\mathrm{m}^{2}\right), m_{d r y}$ is weight of dry sample $\left(\mathrm{kg} / \mathrm{m}^{2}\right)$ per area $S\left(\mathrm{~m}^{2}\right), t$ is time, $\mathrm{H}$ is the height of the sample $(m)$.

\section{Conclusion}

There are only a few research works, which deal with complex heat, air and water transport in sandstones. Transmission parameters were studied by scientist in Canada, Germany and Czech Republic. There were a large number of quarries for sandstone mining in the territory of eastern Slovakia. Sandstone samples were collected from selected historical quarries and found in historical buildings and monuments. Samples were taken from the collected homogeneous sandstones for measuring the water transfer parameter, namely the water 
absorption coefficient and capillary water content, which are one of the important parameters that allow modelling complex heat, air and water transport in buildings. The samples are prepared for one-dimensional transport of water experiment, which indicates capillary moisture transport ability of porous materials.

\section{Acknowledgements}

This work was supported by the VEGA: 1/0674/18 Theoretical and experimental analysis of architectural-structural shapes and fragments of building envelope structures designed for harsh conditions.

\section{References}

[1] Ma, Z. et al. (2012). Existing building retrofits: Methodology and state-of-the-art. Energy and Buildings. Elsevier B.V. 55. pp. 889-902. doi: 10.1016/j.enbuild.2012.08.018.

[2] Asadi, E. et al. (2014). Multi-objective optimization for building retrofit: A model using genetic algorithm and artificial neural network and an application. Energy and Buildings. Elsevier B.V. 81. pp. 444-456. doi: 10.1016/j.enbuild.2014.06.009.

[3] Hendron, R. et al. (2013). Advanced Energy Retrofit Guide (AERG): Practical Ways to Improve Energy Performance; Healthcare Facilities (Book). Golden, CO (United States). doi: $10.2172 / 1096100$.

[4] Zhao, J. and Plagge, R. (2015). Characterization of hygrothermal properties of sandstones Impact of anisotropy on their thermal and moisture behaviors. Energy and Buildings. Elsevier B.V. 107. pp. 479-494. doi: 10.1016/j.enbuild.2015.08.033.

[5] Kočí, V. et al. (2014). Service life assessment of historical building envelopes constructed using different types of sandstone: A computational analysis based on experimental input data. Scientific World Journal. doi: 10.1155/2014/802509.

[6] Krus, M. (1996). Moisture transport and storage coefficients of porous mineral building materials: Theoretical Principles and New Test Methods. Fraunhofer IRB Verlag. Stuttgart.

[7] Zhao, J. and Plagge, R. (2015). Characterization of hygrothermal properties of sandstones Impact of anisotropy on their thermal and moisture behaviors. Energy and Buildings. Elsevier B.V. 107. pp. 479-494. doi: 10.1016/j.enbuild.2015.08.033.

[8] Čabalová, D. and Šamalíková, M. (1992). Inžinierska geológia. Bratislava: Alfa.

[9] Čabalová, D. (2013). Krása kameňa vživote človeka. Bratislava: Veda.

[10] Laho, M. et al. (2009). Výber stavebného kameňa pre rekonštrukciu historických objektov. Acta Geol. Slovaca (AGEOS). 1. pp. 9-14.

[11] Deachman, B. (2018). Q is for Quarry: Forgotten, overgrown quarry provided the building blocks of Ottawa', Ottawa citizen.

[12] Vertal', M. and Ďurica, P. (2013). Prenosové parametre vody vo vybraných stavebných materiáloch. Košice: Technická univerzita v Košiciach, Stavebná Fakulta.

[13] STN EN ISO 15148. (2002). Tepelno-vlhkostné vlastnosti stavebných materiálov a výrobkov. Stanovenie koeficientu nasiakavosti pri čiastočnom ponorení.

[14] STN EN 1926. (2002). Skúšky prírodného kameňa. Stanovenie súčinitel’a nasiakavosti kapilaritou. 
[15] Kočí, V. et al. (2014). Service life assessment of historical building envelopes constructed using different types of sandstone: A computational analysis based on experimental input data. Scientific World Journal. online: https://www.hindawi.com/journals/tswj/2014/802509/fig1/

[16] Gall, Q. Section through Nepean formation sandstone and overlying March formation dolostone and sandstone. online: http://www.stunley.com/ogg/site_2centrum.htm

[17] Énergie et Ressources naturelles. Saint-Canut-Sainte-Scholastique. online: https://mern.gouv.qc.ca/english/mines/industry/architectural/architectural-quarrying-historysandstone-saintcanut.jsp

[18] Bednarik, M. Laho, M. Holzer R. Historic quarries. online: http://saxa.chc.sbg.ac.at/img/quarries/478_2.jpg 